\title{
VALUES CREATED BY MUSIC EDUCATION IN GENERAL COMPREHENSIVE SCHOOLS
}

\author{
Urve Läänemets \\ Estonian Academy of Music and Theatre, Estonia \\ Katrin Kalamees-Ruubel \\ Estonian Academy of Music and Theatre, Estonia \\ Kristi Kiilu \\ Estonian Academy of Music and Theatre, Estonia \\ Kadi Kaja \\ Estonian Academy of Music and Theatre, Estonia \\ Anu Sepp \\ Estonian Academy of Music and Theatre, Estonia
}

\begin{abstract}
This is the final part of research started in 2014 when development of the new National Curricula (NC) was initiated. The role of music education had to be mapped to prove its meaning as a traditional mandatory subject in the NC. According to the research program, different aspects, related to music education (content, integration of art subjects, informal and non-formal music activities, supportive learning environments, etc.), were analysed. The research of 2020 is summarising the values music education can provide for development of educated, responsible, ethical and creative people. The data collected from essays of school students and (future and in-service) music teachers $(n=166)$, were analysed by qualitative methods. The values were classified by the following categories: social, cultural, cognitive, moral, aesthetic, personal. The research results can be used as arguments for developing music education syllabi in the NCs from kindergartens to gymnasia. The whole program of research is already being used for further development of music teacher education.
\end{abstract}

Keywords: identity building, music education in NC, music teacher training, values provided by music education.

\section{Introduction}

Music education at schools has been a topic for discussion among different social groups at different times. Politicians, curriculum developers, school leaders, teachers and parents have often questioned the role of music education as a mandatory school subject and in the majority of countries it has become an optional field of studies after primary grades. Estonia has been and still is an exception where music has a very special meaning and value in society. Music in this country is often called the second mother tongue after Estonian, our native 
language, and our tradition of song festivals, uniting people of different ethnic origin into a nation and cohesive society is over 150 years old. In critical political periods musical activities were a part of resistance culture. It means that the role of music education has been recognized as something especially significant not only for public education, but also something that individual people residing in Estonia accept as a value. Accordingly, Estonia is the only country in the world where music education is provided throughout all the cycle of general education starting from kindergartens and ending up with the final grade of high schools. It is a cultural landmark that has to be preserved, not lost to the global educational reform movement.

However, activities for development new NCs have never stopped and are in full swing now. Following the global OECD and regional EU recommendations, new discussions are there, as other countries have also questioned the need to offer music education for everybody. There are basically two arguments: firstly - not everybody is interested in music, or talented in the field, and secondly: music education is very expensive. Understandably, music teacher education lasts considerably longer as future teachers usually start already at music schools for children and, after attending specialised music classes or studios, proceed at conservatory level, using all 5 years of academic studies (BA+MA) to become a professional music teacher. In addition, music instruments needed are costly. The third resource - time for rehearsals and choir exercises is also necessary. Young people in welfare societies have more diverse interests than music only.

As research in curriculum theory and practice has shown, the content of every school subject represents a summary of human experience in the respective field, which has a different functional potential in people's lives. The perennial question - what is really worth learning in the 21st century schools, needs an answer again. The developers of the new NC have asked to provide arguments for all school subjects, why mother tongue, math, or music should be included into school curricula, providing education for all the population.

A team of lecturers at Estonian Academy of Music and Theatre devised a plan to research the meaning and opportunities for music education at Estonian general comprehensive schools in 2014. It has developed into a small lab, led by professor Kristi Kiilu, and we have mapped different aspects of music education (content, integration of art subjects, informal and non-formal music activities, supportive learning environments, etc.), the results of which have also been presented at local and International conferences (Kiilu, Läänemets, \& KalameesRuubel, 2020; Läänemets, \& Kalamees-Ruubel, 2015; Läänemets \& KalameesRuubel, 2016; Läänemets, Kalamees-Ruubel, Kiilu, \& Sepp, 2018; Läänemets, Kalamees-Ruubel, Sepp, \& Kiilu, 2019; Sepp, Läänemets, Kalamees-Ruubel, \& Kiilu, 2017). This study is the final part of the program, summarising the 7-year Project. We are grateful to students, professional teachers, experts, parents and 
opinion leaders, who have participated in the program during these years, carried out without any grants provided by the state.

The fundamental research problem for all these years has been to prove the value and meaning of music education for Estonian society, people and culture to be preserved and developed as a tradition and a meaningful school subject in the NC. The goal of the final part of the research of 2020 has been to collect arguments characterising the potential of music education for development of a personality and culture at large as perceived by students and teachers, which would justify its position in the NC.

\section{Theoretical Background}

Music has rather different positions in societies and cultures, including school cultures. Philosophical studies in the field of music education have specified different values. Thomas A. Regelski (2002) postulates intrinsic, extrinsic contributory and instrumental values. Heidi Westerlund (2008) provides sound arguments for justification for wider music education, by analyzing its social and individual meaning, especially considering Dewey's theory of experience. It is just the place to recall Dewey's famous idea of every culture having its collective individuality (Dewey, 2019, 335). Even China has taken steps to promote musical diversity in the curriculum (Wing-Wah Law \& WaiChung Ho, 2009).

David J. Elliott has summarized the values of music education as follows: "Music making is a unique and major way of gaining self-growth, self-knowledge, and optimal experience, both now and in the future. And to the extent that these values are achieved in and through the development of musicianship, musicing is also a unique and major way of developing self-esteem. For these reasons, music making is something worth learning to do well by all students." (Elliot, 1995, p. 122).

The well-known quote by Carl Orff says: "Music begins inside human beings, and so must all instruction." This idea has been recognized wherever education has served humanistic purposes. (Orff, 1932, as cited in Salmon, 2012) However, music plays a considerably greater social and educational role. Hannele Niemi (2009, p. 28) says: "Every society needs for its existence specific moral and cultural values, which help to deal with social problems. A biologically born person, must be born into the culture of its society as well.” Maia Muldma and Kristi Kiilu (2012) emphasize that values education is not merely about learning facts and formulae or maintaining discipline, but providing students with opportunities to learn making morally sound decisions, based on ethical principles and cultural awareness. Music education at schools is not meant for training 
professional musicians but for showing students the way, how to become an educated and responsible human being.

Estonian example of music education deserves particular attention, "as music as a school subject fulfils objectives related to values and values education more widely in the society by supporting interpersonal relations, creating social cohesion and laying the foundation for creating and/or reviving and maintaining the notion of tradition.” (Ross, 2007, p.174). Riho Päts, one of the founding fathers of Estonian music education considered joint singing, especially choir singing one of the greatest socio-emphatic skills people can acquire (Raudsepp, 2013).

Forest Hansen, analyzing and comparing school subjects stresses the objective character of sciences and math and highlights stronger value orientation of social and art studies, including music (Hansen, 1994). Wayne Bowman (2012) brings forward the role of musical activities and events for development of social skills and comprehension of cultural values. Joan Russell \& Michalinos Zembylas (2007), when analyzing arts' integration in the curriculum, find music useful for making intensive schooldays more interesting and reducing stress.

Shirley Salmon (2012) highlights the social value of music education. Not all families can provide their children with access to musical activities, so the school can do it, maybe even discover young talents. More important is the early musical experience which can make a difference for a person's all future life. The same idea - the value of pre-school music education - has been analysed by Kristi Kiilu in her dissertation of 2010, providing a historical-critical overview of 19052008. Development of children's cognitive skills through music education is extremely important for their school readiness. Ilsija Nigmatullina (2007) stresses the potential of music to influence children and develop their aesthetic and ethical comprehension. She considers music an artistic reflection of life, greatly contributing to development of students social skills, and also recommends to start with music education earliest possible.

The well-known fact is that nothing happens at school without dedicated professional music teachers and there is ample research in this field (Sepp 2014a, 2014b). Virginia Richardson \& Catherine Fallona (2001) stress the role of teachers as independently thinking creative professionals, able to explain values, create supportive learning environments. The same idea is expressed by Arvydas Girdzijauskas (2007), discussing development of students' moral culture by art subjects. It has to be admitted that professional music teachers at school are very special people - the cultural envoys of the national traditions and world culture, who are intellectuals and professionals in the best sense of the word, students consider to be examples to follow (Läänemets, 2013; Muldma, 2004).

Theoretical research has highlighted rather diverse value aspects and meaning of music education for society and the role of professional music 
teachers for its implementation. Periodical monitoring, how students and society at large accept values offered by music education, is of utmost importance for development of NC for schools.

\section{Aims, Research Questions, Methods}

The aim of the current study was to collect and analyse material characterising music education at schools as perceived by the two most important groups - by the learners at schools with two subgroups (junior and high school students) and music teachers with two subgroups (in-service teachers and future music teachers at the academy), which can provide arguments from different viewpoints.

The research questions were:

1. How do different age-groups of students understand and evaluate music education at school?

2. What makes meaning for students in music lessons and extracurricular music activities?

3. What statements can be found and used for future development of a music syllabus in the NC?

The study of 2020 used a random sample of 166 respondents, representing the 4 afore-mentioned target groups: 1) students of final grades of compulsory schools ( $n=94), 2)$ students of high schools $(n=30), 3)$ future music teachers, still studying at the academy $(n=20)$ and 4$)$ in-service teachers $(n=22)$. The students were asked to write an essay about positive and valuable contributions learning music has made on their individual development. They were also asked to make some proposals for making music lessons more interesting and meaningful. Both groups of teachers were asked to write essays about values music education at schools can contribute to human development. Their essays were based on observations from school practice and personal experience.

The data were analyzed qualitatively by using content analysis (Cohen, Manion, \& Morrison, 2007) with the conventional approach. Considering the possibilities of carrying out analysis (conventional, directed and summative) as suggested by Hsieh \& Shannon (2005), the approach used in this research analysis is conventional as the coding categories are directly derived from the text data. The advantage of this approach allows to gain direct information from study participants without imposing preconceived categories or theoretical perspectives, which suits best considering the material collected.

The data have been analysed from two perspectives: 1) junior and high school students' perceptions of the meaning and value of music education as a school subject; 2) in-service and future music teachers' perceptions. The categories and framework of analysis are the same for all target groups, and they 
are based on what the respondents have highlighted as being of value considering both the content of music education and the process of learning. The values participants ascribed to music education has been categorised as social, cultural, cognitive, and personal, including moral and aesthetic dimensions, and are supported by relevant quotes. Considering the full amount of statements, only the most characteristic ones are presented in this article. The quotes have been provided with abbreviations specifying the group the respondent belongs to: junior students - JR; high school students - HSS; future music teachers - FMT and in-service music teachers - ISMT. The number after the abbreviation refers to the concrete respondent. A review of results is presented by research questions.

\section{Results and Discussion}

The results of the research have been grouped by established qualitative categories and provided with some of the most eloquent examples. All the collected data can be used for further analyses. However, the majority of teachers, both in-service and still in their studies have taken a wider philosophical view about the role of music education. They generally share the opinion, according to which it has a special value for the country and social cohesion as music has been uniting people as a tradition at different times, from past to the present. An inservice music teacher has expressed it as follows: Music is one of the seven ancient liberal arts upon which all European education has been built from those days up to the present. (ISMT 17)

We will proceed with presentation and analysis of results according to the questions asked. The values of music education, different groups of students and teachers have highlighted and considered important, can be classified as follows.

\section{The greatest potential of music education- the means for development of social skills}

The data showed that all respondent groups perceive the greatest value and potential of music education for development of students' social skills. The respondents have highlighted singing together, which develops the sense of belonging and responsibility: It is good to sing together, it develops communication skills and a sense of belonging (JS 17); When singing together we communicate with each other, it creates a feeling of safety and at the same time, you feel the enhanced quality and power when we perform together (HSS 21).

When singing in choir development of social skills leads to realisation of the value of collective achievement (FMT 20) and everybody understands that they all can contribute to collective achievement (HSS 24). 
Music education also has a potential for development of cooperative skills, which a junior student (87) characterized as follows: Group work has developed our cooperation skills and it is important for the future.

Development of the sense of responsibility was also highlighted: It makes you feel responsible for doing your part and rehearsing all together allows you to experience success when we have performed well. (HSS 13) When making music together either in group work or other joint activities, common values become understood and accepted, which a teacher (INMS 19) summarized in the following way: A choir is like a big family, it supports cohesion, and it makes students aware of collective values.

The factor initiating development of social skills in music education is experience and sharing of positive emotions: Playing different instruments and making music together creates many positive emotions you can share with others. (HSS 7)Positive emotions in turn help to reinforce and sustain motivation for learning music: Group projects can increase your motivation for teamwork and lead to a better understanding of your peers. (JS 76)

Comprehension of tolerance and cultural awareness of differences are also meaningful for respondents, when developing their social attitudes, for which music education can provide ample experience. You don't have to like everything, but you learn to understand that people can have different preferences. (JS 54).

This study has confirmed the importance of social values through music education as already found by Heidi Westerlund (2008), with special stress on music philosophy specified by Wayne Bowman (2012) as well as with pedagogical views expressed by Shirley Salmon (2012). At the same time the significance of joint singing and musicking stands out as it was already presented in the study by Inge Raudsepp (2013).

\section{Development of cultural knowledge and widening students' horizons}

Respondents of all groups confirmed great power of music education for acquisition of cultural knowledge. An answer given by a teacher clearly characterizes it: Music helps to develop cultural awareness and mutual understanding (ISMT 6). Students learn to comprehend the value of culturerelated knowledge when studying development of music as a field of human experience and professional skills related to that. A junior student said: Music lesson is the only place where it has been explained to me what classical music is (JS 82). Activities related to learning to play some instrument (Orff-instruments, recorder, zither, guitar) in a class are considered useful and meaningful for broadening one's horizons, and so are the studies of music history: You learn about outstanding composers and their works, and you even start to recognise some melodies (JS 43). The history of music offers material about many different styles of music (HSS 18) and besides traditional classical music students are 
introduced to different styles of contemporary music in all its richness and diversity.

When learning about music of other ethnic groups, students also start to better comprehend their own culture and deeper perceive its specific essence: Music lessons have made me respect our Estonian culture and understand that culture is always related to people (JS 90).The respondents stressed the value of good and diverse selection of the content of current Estonian music education, considering the repertoire, genres, music of different eras and ethnic groups; they considered it to be the basis for all their cultural knowledge in the field of music. Listening to different types of music is really surprising and educational. (HSS 28) Music helps to develop cultural awareness and mutual understanding (ISMT 3).

Earlier research (Kiilu and Muldma 2012) has also highlighted widening students' cultural horizons and their development as educated individuals as aims for music education. Similar to statements made by Jaan Ross (2007) the issue of social cohesion and reviving and maintaining notion of tradition was confirmed. The same can be said about Wayne Bowman's (2012) comprehension of cultural values.

\section{Development of cognitive skills}

The answers given in this category highlighted the general potential of music for development of cognitive skills, but also for enhancement of intellectual skills and emotional intelligence. All music is a powerful tool for the development of emotional intelligence and cognitive development in general (FMT 12). New knowledge of music history and musical examples in the lessons can greatly contribute to the development of students' intellectual skills (ISMT 4).

Acquisition of cognitive skills was observed as valuable for perception of the quality of the sound, comprehension of the mood of a piece of music, which contribute to development of musical memory, melody, rhythm and harmony. The respondents also brought to the foreground the emotional potential and character of a music lesson for creating supportive learning environments for development of cognitive skills. Now we can recognise the sound of instruments in ensembles and orchestras when listening to music (JS 53). I think the emotional side of music lessons is really important - a beautiful piece of music, its melody or character (HSS 30). Comprehension of students' individual potential to express oneself by means of music greatly increases their self-esteem and dignity, as music lessons provide them opportunities to learn about themselves. As a high school student (23) said: Musical self-expression can be different, but there is always something to discover. All groups of respondents stressed the value of becoming brave enough to express their emotions, as this opportunity is usually offered in music lessons only. When students listen to different types of music, they learn to 
understand different emotions and they also learn to react and not be ashamed of showing their own emotions (FMT 14). Arvydas Girdzijauskas (2007) has stressed the importance of moral culture present in all art subjects, and the same was confirmed by this piece of research.

\section{Development of personal skills, including moral and aesthetic dimensions}

The respondents also confirmed that their personal presentation and performing skills have greatly improved through activities they have been involved in in music lessons: I have learned how to behave when performing in public (JS 13).They also highlighted the potential of music for regulation of mood and support motivation for learning, which can be used individually at the needed moment: Nice songs related to different seasons improve your mood (JS 12)....it helps you to calm down when school days are really hard (JS 36).

In the same category, comprehension of students' personal development through their peers' feedback became evident, which again shows the significance of the social aspect of all music education: I have come to understand that it is normal for people to have different ways of expressing themselves (JS 4). I have learnt to assess my abilities more accurately (JS 77).

Responding teachers indicated that it was possible to enhance students' dignity and self-confidence through music education, as they also learn to find arguments when having discussions on musical topics: I think music lessons and our discussions have made them somehow more dignified. They have started to behave more politely (ISMT 18). They have started to talk about musical taste and discuss why they like a particular piece of music (ISMT 6).

\section{Making meaning for students in music lessons and extracurricular music activities}

Considering the collected data, it can be claimed that meaning of any learning is usually made by a professional and dedicated teacher. The teacher of that kind is usually at the same time a good professional musician able to play several instruments and sing well in tune: Our teacher is a good musician, he also plays in an orchestra and has two high-level choirs (JS 56). In addition to pedagogical competences and professional music skills, the teacher also shows respect towards Estonian national music culture and makes students understand and accept these values. Our teacher has led us to respect Estonian music and culture (JS 86); Our teacher does everything with passion (JS 85).

Students of both age-groups are particularly pleased with creative, friendly and supportive atmosphere in music lessons, which supports acquisition of musical literacy, instrument playing skills, and knowledge about history of music. All field trips, related to concerts and other music events as well as other musical 
extra-curricular activities are popular and meaningful for students. Our music lessons are always enjoyable. [The teacher] creates a good and peaceful atmosphere (JS 42). ... we can become educated "consumers" of music and attend concerts. One starts to understand that concert experiences are special, and can be beautiful (JS 27).

Music education at school also guarantees the sustainability of the Song Celebrations' tradition. It sounds patriotic in a way, but it is something we have and others don't. I think that if you respect your country and your culture, you also respect yourself (JS 82).

School music has also helped to create music traditions in families. People always sing on birthdays and other occasions. If you have started to attend concerts and theatre performances, you tend not to stop. It becomes a habit, as it gives so much emotionally. It also has a moral dimension that sometimes makes you strive to be a better person. Also cultural and national studies analysed by Maia Muldma (2004) and Hannele Niemi’s principle of cultural growth (2009) were confirmed.

\section{Future development of a music syllabus in the NC}

Suggestions from students also deserve attention for development of future music syllabi in NC. Junior students wanted to have more time for music lessons, more time for playing instruments, more concert films, more videos of famous performers, and more opportunities to perform and demonstrate what they have learned. They also wanted more group work and less theory, and complained about being really tired on some long schooldays with difficult subject lessons. In those cases, they simply have too little energy for singing.

High school students were very satisfied with music lessons as they widen our horizons, and if you want to be considered an intelligent person, you should also know something about music. They wanted more films with opera and concert performances to be shown in lessons or at extra-curricular events, preferably in the company of partner schools.

All the research questions of 2020 were answered, and the collected materials are still available for further analyses and discussions. The rich data collected by this research allow to draw conclusions within this sample, but they also indicate, what the trends in the Estonian society at large are.

\section{Conclusion and Recommendations}

The research results of 2020 as well as the previously collected and analysed data over the course of the seven-year project can be used for several purposes. First, it has demonstrated the multiple benefits of music education for learners of different ages from the standpoint of their social, intellectual, moral and emotional 
development. Second, it has great potential for the development of social skills as well as societal cohesion. Third, music education has great value with regard to making national music traditions sustainable, as well as developing educated audiences for cultural events. Fourth, the project materials provide information for updating the syllabus for music education in the NC. Fifth, the research results would also facilitate the development of music-teacher-training curricula as well as supportive learning environments in Estonian general comprehensive schools.

The conclusion is: it is possible and important to provide opportunities for learning music to everybody. Music education can greatly contribute to development of any society and its people, if its aims, content and possibilities of implementation have been rationally planned, and if there are professional and dedicated music teachers available to put it into practice. Music makes meaning.

\section{References}

Bowman, W. (2012). Music's Place in Education. In G. E. McPherson \& G. F. Welch (Eds.), The Oxford Handbook of Music Education, Volume (21-39). New York: Oxford University Press.

Girdzijauskas, A. (2007). Development of moral culture of students while teaching art courses. Problems in music pedagogy, vol. 1, 20-27.

Cohen, L., Manion, L., \& Morrison, K. (2007). Research Methods in Education. London: Routledge.

Dewey, J. (2019). Kunst kui kogemus. Tallinn: Tallinna ülikool.

Elliott, D.J. (1995). Music Matters. A New Philosophy of Music Education. New York: Oxford University Press.

Hansen, F. (1994). Values in Music Education. Philosophy of Music Education Review, 2(1), 3-13. Bloomington: Indiana University Press. Retrieved from: https://www.jstor.org/ stable/40327065.

Hsieh, H.-F., \& Shannon, S. E. (2005). Three Approaches to Qualitative Content Analysis. Qualitative Health Research, 15(9), 1277-1288. DOI:10.1177/1049732305276687.

Kiilu, K. (2010). The development of the concept of music education in Estonian kindergartens, 1905-2008: A historical-critical overview. Doctoral dissertation. University of Helsinki, Faculty of Behavioural Sciences, Department of Teacher Education, Research Report 314.

Kiilu, K., Läänemets, U., \& Kalamees-Ruubel, K. (2020). Skills for creating supportive learning environments - an essential component of teachers' professional competence. Society. Integration. Education. Proceedings of the International Scientific Conference. Volume III, Rēzeknes Tehnologiju akadēmija, 302-315.

Läänemets, U. (2013). Didaktika Minima. Tallinn: Juura.

Läänemets, U., Kalamees-Ruubel, K., Sepp, A., \& Kiilu, K. (2019). Traditional values in the era of technology and innovation. Society. Integration. Education. Proceedings of the International Scientific Conference, Volume I, Rēzeknes Tehnologiju akadēmija, 320-330.

Läänemets, U., Kalamees-Ruubel, K., Kiilu, K., \& Sepp, A. (2018). Curriculum development considering formal, non-formal and informal education. In: Society. Integration. Education. Proceedings of the International Scientific Conference, Volume II, Rèzeknes Tehnologiju akadèmija, 286-295. 
Läänemets, U., \& Kalamees-Ruubel, K. (2016). Integrated language learning in Estonian national curricula (NC) for general comprehensive schools. In: Society. Integration. Education. Proceedings of the International Scientific Conference,. Volume II, Rēzeknes Tehnologiju akadèmija, 143-153.

Läänemets, U., \& Kalamees-Ruubel, K. (2015). Content, identity building and national curricula. Society. Integration. Education. Proceedings of the International Scientific Conference, Volume II, Rēzeknes Tehnologiju akadēmija, 114-124.

Muldma, M. (2004). Fenomen muzõki v formirovanii dialoga kultur. Sopostavitelnõi

Analiz mnenii utšitelei muzõki škol s estonskim i russkim jazõkom obutšenija. (n.d.). Doktoritöö. Sotsiaalteaduste dissertatsioonid nr 13, Tallinn: Tallinna pedagoogikaülikooli kirjastus.

Muldma, M., \& Kiilu, K. (2012). Teacher`s view on the development of values in Music education in Estonia. The 5th Intercultural Arts Education Conference: Design Learning. Procedia - Social and Behavioral Sciences, 45, 342-350. Elsevier Ltd.

Niemi, H. (2009). Õpetaja väärtuste kandja ja vahendajana. In M. Sutrop, P. Valk, \& K. Velbaum (Eds.), Väärtused ja väärtuskasvatus: võimalused 21. Sajandi Eesti ja Soome koolis (27-49). Tartu: Tartu ülikooli eetikakeskus.

Nigmatullina, I.K. (2007). Vospitanie nravstvennoj lichnosti v obshheobrazovatel'noj shkole sredstvami muzyki. Retrieved from https://urok.1sept.ru/

Raudsepp, I. (2013). Riho Pätsi fenomen Eesti muusikapedagoogikas. Doktoritöö. Kasvatusteaduste instituut. Sotsiaalteaduste dissertatsioonid $n r$. 66. Tallinn: TallinnaÜlikool.

Regelski, T.A. (2002). Musical Values and the Value of Music Education. Philosophy of Music Education Review, Volume 10, Number 1, 49-55. Indiana University Press.

Richardson, V., \& Fallona, C. (2001). Classroom management as method and manner. Journal of Curriculum Studies 33(6), 705-728. DOI: https://doi.org/10.1080/ 00220270110053368.

Ross, J. (2007). Kaksteist loengut muusikapsühholoogiast. Tartu: Tartu Ülikooli Kirjastus.

Russell, J., \& Zembylas M. (2007) Arts Integration in the Curriculum: A Review of Research and Implications for Teaching and Learning. In: L. Bresler (Ed.), Springer International Handbook of Research in Arts Education, Vol. 16, (287-312). Dordrecht: Springer.

Salmon, S. (2012). Musica Humana - Thoughts on Humanistic Aspects of Orff-Schulwerk. In B. Haselbach (Hg), Orff-Schulwerk Informationen 87. The Three Pillars of OrffSchulwerk. Winter 2012. Salzburg: Universität Mozarteum, Carl Orff Institut und OrffSchulwerk Forum.

Sepp, A. (2014a). From music syllabi to teachers' pedagogical thinking: a comparative study of Estonian and Finnish basic school music education. Doctoral dissertation. University of Helsinki, Faculty of Behavioural Sciences, Department of Teacher Education, Research Report 359.

Sepp, A. (2014b). Muusikaõpetaja rollist üldhariduskoolis. In K. Kiilu, \& A. Sepp (koost.), Muusikaõpetuse didaktika (32-38). Tallinn: Eesti Muusika- jaTeatriakadeemia.

Sepp, A., Läänemets, U., Kalamees-Ruubel, K., \& Kiilu, K. (2017). Art subjects in national curricula - ideas for future developments in general education. Society. Integration. Education. Proceedings of the International Scientific Conference. Volume II, Rēzeknes Tehnologiju akadēmija, 197-207.

Westerlund, H. (2008). Justifying Music Education: A View from Here-and-Now Value Experience. Philosophy of Music Education Review, 16(1), 79-95. Indiana University Press.

Wing-Wah, Law \& Wai-Chung, Ho. (2009). Globalization, values education, and school music education in China, Journal of Curriculum Studies, 41(4), 501-520. DOI: https://www.tandfonline.com/doi/abs/10.1080/00220270802372329 